\title{
Biochemical and quality changes occurring in donkey milk subjected to non-standard heat treatments
}

\author{
Ichrak Charf ${ }^{1,2}$, Flavio Tidona ${ }^{3 *}$, Anissa Makhlouf $f^{4}$, Feriel Rezouga ${ }^{1,2}$, Haythem Boukhari $^{2}$ and Salwa Bornaz ${ }^{2}$ \\ ${ }^{1}$ Département de Génies Biologique et Agroalimentaire, Université Libre de Tunis, 30 Avenue Kheireddine Pacha,1002 Tunisa \\ ${ }^{2}$ Département de Sciences et Technologies des Aliments, Ecole Supérieure des Industries Alimentaires de Tunis, 58 Avenue Alain Savary, 1003 Tunis, Tunisia \\ ${ }^{3}$ Consiglio per la ricerca in agricoltura e l'analisi dell'economia agraria - Centro di Ricerca Zootecnia e Acquacoltura (CREA-ZA), Via Antonio Lombardo 11, \\ 26900, Lodi, Italy \\ ${ }^{4}$ Laboratoire de Génie Industriel (LGI), Centrale Supélec, Grande Voie des Vignes, Châtenay-Malabry, France
}

\begin{abstract}
Non-standard heat treatments, i.e. $68^{\circ} \mathrm{C} 2.5 \mathrm{~min}^{-1}, 75^{\circ} \mathrm{C} 10 \mathrm{~min}^{-1}$ and $100^{\circ} \mathrm{C} 5 \mathrm{~min}^{-1}$, were applied to evaluate the effects on physicochemical and microbiological characteristics of donkey milk compared to bovine milk. The most significant $(P<0.05)$ changes were the decrease of $\mathrm{pH}$, the increase of casein nitrogen and the denaturation degree of whey proteins, which exceeded $80 \%$ in donkey milk compared to about $66 \%$ in bovine milk, at $100^{\circ} \mathrm{C} 5$ min ${ }^{-1}$. Conversely, calcium and phosphorus were more heat stable in donkey milk than in bovine milk. Hydroxymethylfurfural (HMF) resulted absent in donkey milk. Significant changes in free fatty acids (FFA) were observed in both heated milks, although donkey milk showed lower lipolysis rates. The lysozyme activity of donkey milk was inversely related to the intensity of heat treatments but even at $100^{\circ} \mathrm{C} 5 \mathrm{~min}^{-1}$ a relevant activity was still observed.
\end{abstract}

\section{Introduction}

The most abundant milk all over the world is bovine milk and it is generally used as a substitute of human milk when breastfeeding is not possible or after weaning. Nevertheless, bovine milk protein may cause an abnormal immunological response, affecting $3 \%$ of infants before the age of 3 years. Among dairy species, donkey milk has been considered a suitable solution rather than commercial infant formulations, thanks to its hypoallergenic properties, chemical composition close to human milk, particularly for the protein profile [1-3]. Donkey milk production is limited and it has generally a local market, therefore it is necessary to put in place suitable processing methods for its preservation and utilization, given the different donkey breeding system, compared to ruminants, and the peculiar characteristics of donkey milk.

Thermal treatments are commonly used to ensure safety requirements and extend milk shelf life. The effect of heat treatment on the nutritional quality of various milks were studied [4-6]. However, few studies were addressed to evaluate the effects of heat treatments on donkey milk regarding destruction of microorganisms and quantification of the chemical changes $[7,8]$. Thermal damages depend on both temperature and time applied, causing degradation of milk components such as lactose, denaturation of whey proteins, destruction of enzymes and hydrolysis of proteins and lipids. Several by-product components were also produced during heating, therefore the nutritional value of milk decreases and worsens during the storage. According to European regulations, for the short heat treatment of bovine milk, a temperature between 72 and $75^{\circ} \mathrm{C}$, for $15-30 \mathrm{~s}$ should be applied [9]. However, the treatment of donkey milk is not specifically regulated and standard heat treatments may not be suitable for donkey milk. Little information is available about pasteurization of equid milk and in Italy it is processed by some donkey breeders in small scale conditions, applying a pasteurization process at $68^{\circ} \mathrm{C} 2.5 \mathrm{~min}^{-1}$ [10].
In this work, donkey and bovine milks were subjected to previously mentioned pasteurization and to two more severe thermal processing. The aim of the study was to evaluate changes, in terms of chemical and microbiological characteristics, affecting the nutritional quality and safety of donkey milk in comparison with bovine milk.

\section{Materials and methods}

\section{Milk samples}

Donkey bulk milk was collected from jennies of circummediterranean race (Equus africanus asinus) from the region of Sidi Thabet (Ariana, Tunisia). Jennies, fed solely on pasture and hay addition, were milked manually 3 times day ${ }^{-1}$. Foals were separated physically but adjacently to jennies $3 \mathrm{~h}$ before the first milking, maintaining the visual and acoustic contact. Bovine bulk milk was collected from Holstein cows reared in a farm in the same region. Samples of donkey and bovine milk were immediately cooled, transported within $2 \mathrm{~h}$ to the laboratory under refrigerated conditions and stored at $4^{\circ} \mathrm{C}$. Upon arrival, milk samples were homogenized and divided into $250 \mathrm{~mL}$ sterile Pyrex glass bottles.

\section{Heat treatments}

Heat treatment experiments of donkey and bovine milks were conducted in glass bottles dipped in water bath. Three different conditions of temperature and time were studied: $68^{\circ} \mathrm{C} 2.5 \mathrm{~min}^{-1}, 75^{\circ} \mathrm{C}$

${ }^{\star}$ Correspondence to: Flavio Tidona, Via Antonio Lombardo 11, 26900, Lodi, Italy, Tel: +39-0371-40471; Fax: +39-0371-31853; E-mail: flavio.tidona@crea.gov.it

Key words: donkey milk, heat treatments, damage, denaturation, lysozyme

Received: June 21, 2019; Accepted: July 17, 2019; Published: July 22, 2019 
$10 \mathrm{~min}^{-1}$ and $100^{\circ} \mathrm{C} 5 \mathrm{~min}^{-1}$, and quickly cooled. To ensure an effective monitoring of time and temperature during the heat treatment, one aliquot was equipped with a thermal probe. When the target temperature was reached, samples were kept the established time and then cooled to $4^{\circ} \mathrm{C}$ in ice water and stored at $-18^{\circ} \mathrm{C}$. Thermal curves during the treatments were recorded by a data logger and experiments were reproduced 3 times. Before analysis, samples were thawed overnight at $4^{\circ} \mathrm{C}$. The same protocol and the same conditions were applied to bovine milk. Four raw milk samples of each milk type were kept as control.

\section{Microbiology analysis}

To evaluate the effectiveness of the heat treatments applied, microbiological analysis were performed to raw and heat-treated samples of both donkey and bovine milks. Total bacterial count was determined on PCA at $30^{\circ} \mathrm{C}$ for $72 \mathrm{~h}$. Enterobacteriaceae were enumerated on violet red bile glucose (VRBG) plates and incubated at $37^{\circ} \mathrm{C}$ for $24 \mathrm{~h}$. Total coliforms and fecal coliforms were counted on violet red bile lactose (VRBL) agar plates (Oxoid SpA) and incubated at $37^{\circ} \mathrm{C}$ and $44^{\circ} \mathrm{C}$ for $24 \mathrm{~h}$, respectively.

\section{Composition analysis and $\mathrm{pH}$}

The $\mathrm{pH}$ was measured by a $\mathrm{pHmeter}$ (Model C860, multi parameter analyser, Turnhout, Belgium). Dry matter was determined by oven drying at $105^{\circ} \mathrm{C}$, and total ash was obtained gravimetrically after the dry ashing at $530^{\circ} \mathrm{C}$ according to the AFNOR methods [11]. Lactose in milk was determined by colorimetric dinitrosalicylic acid (DNS) method [12]. The fat content of milk was determined using the Gerber method (ISO1211 2010). Different nitrogen fractions of milk (total nitrogen $[\mathrm{TN}]$, non-protein nitrogen [NPN] and non-casein nitrogen [NCN] were obtained and determined by the Kjeldahl method according to the ISO 8968-1 official method in order to calculate the concentrations of total protein $[\mathrm{TP}=\mathrm{TN} \times 6.38]$, casein $[\mathrm{TC}=(\mathrm{TN}-\mathrm{NCN}) \times 6.38]$ and whey proteins $[\mathrm{WP}=(\mathrm{NCN}-\mathrm{PN}) \times 6.38]$. Denaturation was calculated as follows: $\left[\left(\mathrm{WPN}_{\text {raw milk }}-\mathrm{WPN}_{\text {treated milk }}\right) / \mathrm{WP} \mathrm{raw} \mathrm{milk}\right] \times 100$, where $\mathrm{WPN}_{\text {raw }}$ is whey protein nitrogen in raw milk and $\mathrm{WPN}_{\mathrm{T}(\mathrm{i})}^{\text {raw milk }}$ is that in treated milk at $\mathrm{T}_{(\mathrm{i})}$.

\section{Free fatty acids}

All milk samples were analyzed for free fatty acids (FFA) and lipolysis was calculated as change in FFA contents as described by [13]. Lipolysis rate was calculated according to the following formula: Lipolysis rate $_{(\mathrm{i})}=\left[\left(\mathrm{Lip}_{\mathrm{T}(\mathrm{i})}-\operatorname{Lip}_{\text {Raw }}\right) / \mathrm{Lip}_{\text {Raw }}\right] \times 100$, Where $\operatorname{Lip}_{\mathrm{T}(\mathrm{i})}$ is lipolysis in milk at temperature $\mathrm{T}_{(\mathrm{i})}$ and Lip $\mathrm{Raw}_{\text {Raw }}$ is that in raw milk.

\section{Calcium and Phosphorus contents}

The soluble phase of heated and unheated milk was separated by high-speed centrifugation in a Sorvall Combi Plus ultracentrifuge (Wilmington, DE, USA). An amount of $30 \mathrm{~mL}$ of milk in polypropylene threaded Oak Ridge bottles with a shoulder and screw cap sealing assembly was centrifuged $(100000 \mathrm{xg})$ using a $50-\mathrm{RT}-1250$ rotor at $20^{\circ} \mathrm{C}$ for $1 \mathrm{~h}$. The supernatant was carefully removed and vacuum-filtered through Whatman $\mathrm{N}^{\circ} 40$ paper [14]. Total and soluble calcium (Ca) contents of milk were determined by Manganimetry [15]. Total and soluble phosphorus $(\mathrm{P})$ levels were determined by a colorimetric method [16] with ammonium molybdate using a UV-Vis spectrophotometer (Shimadzu, Kyoto, Japan).

\section{HMF determination}

HMF concentration was measured by high-performance liquid chromatography (HPLC). Before injection, $10 \mathrm{~mL}$ of milk were digested with $5 \mathrm{~mL}$ of $0.3 \mathrm{~N}$ oxalic acid solution for $1 \mathrm{~h}$ at $100^{\circ} \mathrm{C}$. Milk samples were cooled in ice water, deproteinized with $5 \mathrm{~mL}$ of a trichloroacetic acid (TCA) solution (40\%, $\left.\mathrm{w} \mathrm{v}^{-1}\right)$ and filtered through Whatman No. 42 filter paper.

The mobile phase was prepared with a sodium acetate buffer $(0.08$ $\mathrm{M})$ adjusted with glacial acetic acid to $\mathrm{pH}$ 3.6. A Spherisorb ODS-2 analytical column $(250.40 \mathrm{~cm}, 5 \mathrm{~m}$ particle size, Analytical Tracer) was used with detection at $280 \mathrm{~nm}$ (0.5 s response time). An external standard method was used within the range 2-100 M [17].

\section{Lysozyme activity}

To assess the enzymatic activity of lysozyme, a microbiological assay using a suspension of Micrococcus lysodeikticus as substrate was applied according to a standardized method (Sigma-Aldrich EC 3.2.1.17). Analyzes were carried out on both donkey and bovine milk for comparison.

\section{Statistical methods}

Statistical analyses were conducted in order to find out if there are significant differences between milk samples subjected to heat treatment. Analysis of Variance ANOVA and by the Student's $t$-test using Minitab Software (Minitab Inc., Release 18, 2017) was performed. The Student's $t$-test was also used to compare between raw donkey and bovine milks. Evaluations were based on a significant level of $P<0.05$. All experiments were performed in triplicate and were reported as means \pm standard deviation.

\section{Results and discussion}

\section{Chemical composition and $\mathrm{pH}$}

The chemical composition of raw donkey milk and raw bovine milk is shown in Table 1. The fat content in donkey milk confirmed to be low and dry matter content (8.95\%) was slightly lower compared to values $(9.62 \%)$ previously found [18]. The crude protein fraction was composed of $0.81 \%$ of casein and $0.69 \%$ of whey proteins and our results were in agreement with the data reported in the literature concerning the Italian donkey milk [19]. Regarding the mineral fraction, donkey milk contains $0.71 \mathrm{~g} \mathrm{~kg}^{-1}$ of $\mathrm{Ca}$ and $0.49 \mathrm{~g} \mathrm{~kg}^{-1}$ of $\mathrm{P}$, which is consistent with previous reports [19]. In donkey milk, all the milk solid components showed a lower content $(P<0.05)$ compared to bovine milk (Table 1), with the only exception of whey proteins.

The average $\mathrm{pH}$ of raw donkey milk and the lactose content determined in this study (Table 1) was similar to that reported by Addo and Ferragut [20].

Table 1. Chemical composition of donkey milk compared to bovine milk

\begin{tabular}{|c|c|c|}
\hline & Donkey & Bovine \\
\hline Dry matter $\left({\left.\mathrm{g} 100 \mathrm{~g}^{-1}\right)}^{-1}\right.$ & $8.95 \pm 0.03$ & $12.28 \pm 0.05$ \\
\hline Total nitrogen $\times 6,38$ & $1.71 \pm 0.08$ & $3.46 \pm 0.09$ \\
\hline Proteins (g $\left.100 \mathrm{~g}^{-1}\right)$ & $1.50 \pm 0.07$ & $3.30 \pm 0.08$ \\
\hline Lactose $\left(\mathrm{g} 100 \mathrm{~g}^{-1}\right)$ & $5.85 \pm 0.14$ & $4.80 \pm 0.11$ \\
\hline lipids $\left(\mathrm{g}_{\left.100 \mathrm{~g}^{-1}\right)}\right.$ & $0.8 \pm 0.04$ & $3.30 \pm 0.05$ \\
\hline $\operatorname{Ash}\left(g_{\left.100 g^{-1}\right)}\right.$ & $0.50 \pm 0.05$ & $0.68 \pm 0.03$ \\
\hline Calcium (mg $100 \mathrm{~g}^{-1}$ ) & $48.32 \pm 0.00$ & $52.62 \pm 0.00$ \\
\hline Phosphorus (mg $100 \mathrm{~g}^{-1}$ ) & $41.06 \pm 0.01$ & $47.84 \pm 0.01$ \\
\hline Casein $\left({\left.\mathrm{g} 100 \mathrm{~g}^{-1}\right)}\right.$ & $0.81 \pm 0.02$ & $2.62 \pm 0.04$ \\
\hline Whey protein $\left({\left.\mathrm{g} 100 \mathrm{~g}^{-1}\right)}\right.$ & $0.69 \pm 0.03$ & $0.68 \pm 0.02$ \\
\hline 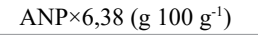 & $0.21 \pm 0.02$ & $0.16 \pm 0.01$ \\
\hline $\mathrm{pH}$ & $7.31 \pm 0.00$ & $6.75 \pm 0.01$ \\
\hline
\end{tabular}




\section{Effect of heat treatments on $\mathrm{pH}$}

Initial $\mathrm{pH}$ of donkey and bovine milk (Table 1) remained invariant after treatments at $68^{\circ} \mathrm{C} 2.5 \mathrm{~min}^{-1}, 75^{\circ} \mathrm{C} 10 \mathrm{~min}^{-1}$ but decreased significantly $(P<0.05)$ to $\mathrm{pH} 7.19$ and 6.66 in donkey and bovine milk respectively, after the most intense treatment at $100^{\circ} \mathrm{C}$ $5 \mathrm{~min}^{-1}$. This decrease is probably related to the thermal oxidation of lactose to organic acids (responsible for $50 \%$ of the lowering of $\mathrm{pH}$ ), mainly formic acid, organic phosphate hydrolysis (responsible for $30 \%$ of the decrease of the $\mathrm{pH}$ ) and finally the precipitation of tricalcium phosphate and the concomitant release of hydrogen ions [21]. The decrease of $\mathrm{pH}$ in donkey milk was significantly higher than that in bovine milk. This is probably due to the richness of donkey milk in lactose (Table 1) which is the first to be responsible for the $\mathrm{pH}$ decrease in milk.

\section{Evaluation on of the Maillard reaction}

To evaluate the impact of heating on lactose, the amount of Hydroxymethylfurfural (HMF) as a product of Maillard reaction, derived after each treatment, was determined. It was observed that HMF was not detected in all donkey milk heated samples. On the other hand, in bovine milk, HMF was absent in the sample pasteurized at $68^{\circ} \mathrm{C} / 2.5 \mathrm{~min}^{-1}$ whereas it was found in the milk treated at $75^{\circ} \mathrm{C} 10 \mathrm{~min}$ ${ }^{1}\left(0.045 \mathrm{mg} \mathrm{L}^{-1}\right)$ and $100^{\circ} \mathrm{C} / 5 \mathrm{~min}\left(0.060 \mathrm{mg} \mathrm{L}^{-1}\right)$. The concentration of HMF increased progressively with the intensity of the thermal process, which is consistent with the results reported by Morales et al. [22] who observed that the high presence of milk fat, as the case of bovine milk, also enhances the formation of free HMF [23]. However other previous studies showed the presence of furosine as Maillard reaction product since it is related to the first stages of Maillard reaction. It is the stable product produced by the acid hydrolysis of unstable lactuloselysine, which is accumulated in heat-treated milks [4], therefore furosine is an appropriate index for all types of heated milks. The absence of HMF in treated donkey milk samples suggests that heating enhanced isomerization of lactose (formation of lactulose) rather than Maillard product formation since the isomerization of reducing sugars in milk is favored at $\mathrm{pH}$ higher than 7.05, which is the case of donkey milk [24].

\section{Effect of heat treatment on fat}

To evaluate fat milk deterioration caused by the heat treatment, the degree of lipolysis was calculated and expressed as the increase of free fatty acid (FAA) contents in milk compared to the raw milk. Result showed that all the heat treatment exerted a significant increase on the degree of lipolysis for both types of milk (Table 2). Initially, it is clear that both raw milks contain low levels of FFA on account of their protective actions of the adsorbed globule surface [25]. In this respect, donkey milk had lower lipolysis level compared to bovine milk probably due to the differences in the structures of fat globule membrane, their fatty acid profiles and in their levels of active fatty acids like caproic,

Table 2. Formation of free fatty acids ( $\mathrm{mEq} 100 \mathrm{~g}^{-1}$ of fat) due to lipolysis induced by the different heat treatments

\begin{tabular}{|c|c|c|c|c|}
\hline \multirow{2}{*}{ Heat treatment } & \multicolumn{2}{|c|}{ Donkey milk } & \multicolumn{2}{c|}{ Bovine milk } \\
\cline { 2 - 5 } & Average \pm SD & Lipolysis rate \% & Average \pm SD & $\begin{array}{c}\text { Lipolysis rate } \\
\%\end{array}$ \\
\hline Raw milk & $0.427 \pm 0.001^{\mathrm{A}}$ & - & $0.743 \pm 0.006^{\mathrm{a}}$ & - \\
\hline $68^{\circ} \mathrm{C} / 2.5 \mathrm{~min}$ & $0.430 \pm 0.001^{\mathrm{B}}$ & +0.25 & $0.782 \pm 0.002^{\mathrm{b}}$ & +3.89 \\
\hline $75^{\circ} \mathrm{C} / 10 \mathrm{~min}$ & $0.442 \pm 0.002^{\mathrm{C}}$ & +1.43 & $0.826 \pm 0.002^{\mathrm{c}}$ & +8.24 \\
\hline $100^{\circ} \mathrm{C} / 5 \mathrm{~min}$ & $0.534 \pm 0.007^{\mathrm{D}}$ & +10.61 & $0.923 \pm 0.001^{\mathrm{d}}$ & +18.00 \\
\hline
\end{tabular}

Values with different superscript letters in the same column are significantly different $(P<0.05)$ with the heat treatment factor. caprylic, capric, lauric and myristic acids that are readily released during triglyceride hydrolysis and contribute in the protective function of milk [26].

The highest FFA increase was reached at $100^{\circ} \mathrm{C} 5 \mathrm{~min}^{-1}$ as expected. However, donkey milk clearly showed a moderate increase of FFA when $68^{\circ} \mathrm{C} 2.5 \mathrm{~min}^{-1}$ and $75^{\circ} \mathrm{C} 10 \mathrm{~min}^{-1}$ heat treatments were applied compared to bovine milk. This increasing trends of the lipolysis' degree observed in the two milks was in agreement with a previous study which demonstrated a significant increase of FFA between pasteurized and raw milk [27]. A possible explanation could be the damage to the milk fat globule membrane, which accelerated oxidative rancidity and this was confirmed by the free-fat (oil-droplets) observed on the milk surface during inoculation of the cheese culture [27]. Differently, a higher level of FFA in raw bovine milk was found compared to the heat-treated milk, due to the activity of lipases which are destroyed by heat treatments $>63^{\circ} \mathrm{C}$ [28].

\section{Thermal markers involved in the nitrogen fractions}

Changes in nitrogenous components in raw donkey and bovine milk after thermal treatments were summarized in Table 3. Results showed that heat treatments do not have a significant effect on total nitrogen (TN) and non-protein nitrogen (NPN) fractions in both types of milk $(P<0.05)$. However, the application of increasing heat treatment intensity affected significantly casein content, which increased, and soluble proteins which decreased in heated donkey and bovine milks. This could be attributed to the co-precipitation of whey proteins and their association with casein micelles. Similar trends were reported when various kinds of milk were heated [29].

The increase in casein content and the decrease in serum protein in donkey milk were more intense than in bovine milk (Table 3). This can be explained by the higher content of serum proteins compared to caseins in donkey milk. In previous foundings, $\alpha$-lactalbumin and $\beta$-lactoglobulin were not significantly detected after a heat treatment of $80^{\circ} \mathrm{C}$ during $60 \mathrm{~min}$ of camel milk, the casein fractions were kept intact whereas serum albumin was found to decrease [30]. In a study regarding the effect of heat treatments on lysozyme, lactoferrin and $\beta$-lactogloblin for donkey milk, the tested proteins confirmed a decrease and lactoferrin showed to be the most sensitive [18]. It was also demonstrated that significant changes in the distribution of denatured bovine major whey proteins between the soluble and the micelle bound complexes were observed. Conversely, all denatured caprine whey proteins, were part of micelle-bound complexes after heat treatment [29].

The level of denaturation of whey proteins was calculated in our work, for all heated milk samples (Table 3). The higher thermal treatment is, the higher is the degree of whey protein denaturation as confirmed by previous studies [18]. Whey protein of donkey milk resulted more sensitive to heat than that of bovine milk as denaturation rates reached $82.89 \%$ and $65.95 \%$ at $100^{\circ} \mathrm{C} 5 \mathrm{~min}^{-1}$, in donkey and bovine milks, respectively. This may be related to its higher WPN content and its casein deficiency as compared to bovine milk.

\section{Changes on the solubility of calcium and phosphorus}

The effect of heat treatment on the solubility of calcium and phosphorus was determined by measuring the relative concentrations of soluble calcium and phosphorus in the aqueous phases of raw and treated milks.

Initial soluble calcium concentrations were $483.23 \pm 0.35 \mathrm{mg} \mathrm{L}^{-1}$ and $526.19 \pm 0.64 \mathrm{mg} \mathrm{L}^{-1}$ in donkey milk and bovine milk respectively. 
Table 3. Changes on nitrogen fractions distribution in milk when different heat treatments where applied

\begin{tabular}{|c|c|c|c|c|c|c|c|c|c|c|}
\hline \multirow[b]{2}{*}{ Treatment } & \multicolumn{5}{|c|}{ Donkey } & \multicolumn{5}{|c|}{ Bovine } \\
\hline & TN & NPN & $\mathrm{CN}$ & WPN & Denaturation \% & $\mathbf{T N}$ & NPN & $\mathrm{CN}$ & WPN & Denaturation \% \\
\hline Raw milk & $0.27 \pm 0.08^{\mathrm{A}}$ & $0.03 \pm 0.015^{\mathrm{A}}$ & $0.13 \pm 0.02^{\mathrm{A}}$ & $0.11 \pm 0.03^{\mathrm{A}}$ & - & $0.54 \pm 0.08^{\mathrm{a}}$ & $0.02 \pm 0.08^{\mathrm{a}}$ & $0.41 \pm 0.04^{\mathrm{a}}$ & $0.11 \pm 0.02^{\mathrm{a}}$ & - \\
\hline $68^{\circ} \mathrm{C} / 2.5 \mathrm{~min}$ & $0.26 \pm 0.05^{\mathrm{A}}$ & $0.04 \pm 0.01^{\mathrm{A}}$ & $0.15 \pm 0.03^{\mathrm{B}}$ & $0.07 \pm .02^{\mathrm{B}}$ & 35.73 & $0.55 \pm 0.05^{\mathrm{a}}$ & $0.03 \pm 0.01^{\mathrm{a}}$ & $0.42 \pm 0.03^{\mathrm{a}}$ & $0.10 \pm 0.03^{\mathrm{a}}$ & 6.97 \\
\hline $75^{\circ} \mathrm{C} / 10 \mathrm{~min}$ & $0.26 \pm 0.03^{\mathrm{A}}$ & $0.04 \pm 0.01^{\mathrm{A}}$ & $0.17 \pm 0.04^{\mathrm{C}}$ & $0.05 \pm 0.04^{\mathrm{C}}$ & 52.06 & $0.55 \pm 0.06^{\mathrm{a}}$ & $0.04 \pm 0.01^{\mathrm{a}}$ & $0.44 \pm 0.03^{b}$ & $0.07 \pm 0.03^{\mathrm{b}}$ & 32.91 \\
\hline $100^{\circ} \mathrm{C} / 5 \mathrm{~min}$ & $0.26 \pm 0.06^{\mathrm{A}}$ & $0.04 \pm 0.01^{\mathrm{A}}$ & $0.21 \pm 0.03^{\mathrm{D}}$ & $0.02 \pm 0.02^{\mathrm{D}}$ & 82.89 & $0.56 \pm 0.035^{\mathrm{a}}$ & $0.04 \pm 0.01^{\mathrm{a}}$ & $0.49 \pm 0.04^{\mathrm{c}}$ & $0.04 \pm 0.04^{\mathrm{c}}$ & 65.95 \\
\hline
\end{tabular}

TN: Total Nitrogen (g $100 \mathrm{~g}^{-1}$ of milk); NPN: Non Protein Nitrogen (g $100 \mathrm{~g}^{-1}$ of milk); CN: Casein Nitrogen (g $100 \mathrm{~g}^{-1}$ of milk); WPN: Whey Protein Nitrogen (g $100 \mathrm{~g}^{-1}$ of milk). Values with different superscript letters in the same column are significantly different $(P<0.05)$ with the heat treatment factor

It was observed that the application of heat treatments tends to reduce the solubility of calcium in both types of milk in all heated samples $(P<0.05)$ (Figure 1A). Results were in agreement with previously reports on bovine milk [14]. Bovine and donkey milks treated at $100^{\circ} \mathrm{C}$ $5 \mathrm{~min}^{-1}$ showed the lowest soluble calcium concentrations $(431.18 \pm 1.95$ $\mathrm{mg} \mathrm{L}^{-1}$ and $463.60 \pm 2.28 \mathrm{mg} \mathrm{L}^{-1}$ respectively). The significant reduction of soluble calcium between raw and treated milk samples may affect their heat stabilities and their subsequent technological uses [14,21]. The initial concentrations of soluble phosphorus were $410.65 \pm 0.47 \mathrm{mg}$ $\mathrm{L}^{-1}$ and $478.44 \pm 0.53 \mathrm{mg} \mathrm{L}^{-1}$ in donkey and bovine milk respectively. Regarding phosphorus, its solubility in donkey and bovine milks also decreased significantly $(\mathrm{P}<0.05)$, progressively with the intensity of the heat treatment (Figure 1B). Donkey and bovine milks treated at $100^{\circ} \mathrm{C} 5 \mathrm{~min}^{-1}$ showed the lowest soluble phosphorus concentrations (200.80 $\pm 0.35 \mathrm{mg} \mathrm{L}^{-1}$ and $203.38 \pm 0.54 \mathrm{mg} \mathrm{L}^{-1}$ respectively). It can be observed that the decrease of soluble phosphorus in the donkey heated samples was less relevant than that in bovine milk. This may be due to the $\mathrm{pH}$ values, $\mathrm{Ca} / \mathrm{P}$ ratio and the protein profiles of these two types of milk [31].

\section{Lysozyme activity}

The average enzymatic activity of lysozyme in donkey milk is slightly reduced by $45640 \mathrm{U} \mathrm{mL}^{-1}$ in raw milk to $40526 \mathrm{U} \mathrm{mL}^{-1}$ for milk treated at $68^{\circ} \mathrm{C} 2.5 \mathrm{~min}^{-1}$. This result were in agreement with these found by Tidona et al. [10] using the same laboratory scale. The treatments at $75^{\circ} \mathrm{C} 10 \mathrm{~min}^{-1}$ and $100^{\circ} \mathrm{C} 5 \mathrm{~min}^{-1}$ applied on donkey milk remarkably reduced the lysozyme activity $\left(31130 \mathrm{U} \mathrm{mL}^{-1}\right.$ and $12324 \mathrm{U} \mathrm{mL}^{-1}$ respectively). Despite the significant decrease in heated samples $(P<0.05)$, at the higher heat treatment $\left(100^{\circ} \mathrm{C} 5 \mathrm{~min}^{-1}\right)$, the lysozyme activity found in donkey milk was still intense, even higher than that reported for human milk [32]. The partial denaturation of lysozyme treated at $80^{\circ} \mathrm{C}$ for $20 \mathrm{~min}$ resulted in a strongly reduced antimicrobial activity compared with the native lysozyme [33]. Other studies investigated lysozyme denaturation after heating, reporting that lysozyme is very thermostable and its thermal denaturation started at elevated heat treatments [18,34]. Coppola et al. [35] mentioned that heat treatments at $90^{\circ} \mathrm{C}$ for $1 \mathrm{~min}$ did not significantly affect donkey milk lysozyme stability when compared to raw milk. However, lysozyme inactivation occurred after $10 \mathrm{~min}$ at $121^{\circ} \mathrm{C}$. Pasteurization preserves most of donkey milk lysozyme activity, exerting its antimicrobial activity against some gram-positive strains and also against some gramnegative strain such as $X$. campestris [7]. In bovine milk, lysozyme activity was not detected even in raw milk before heat treatment application since it has a very low content of this enzyme [36]. This is the reason why donkey milk, at the dosage of $1.1 \%$, was proposed as natural additive in place of egg lysozyme to bovine milk during cheese manufacturing, in order to prevent blowing defects in long seasoned cheeses [37].

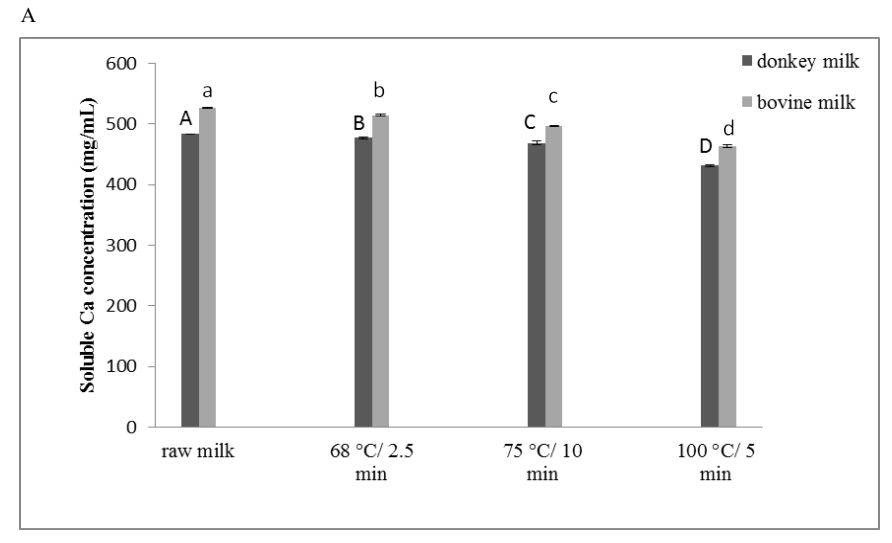

B

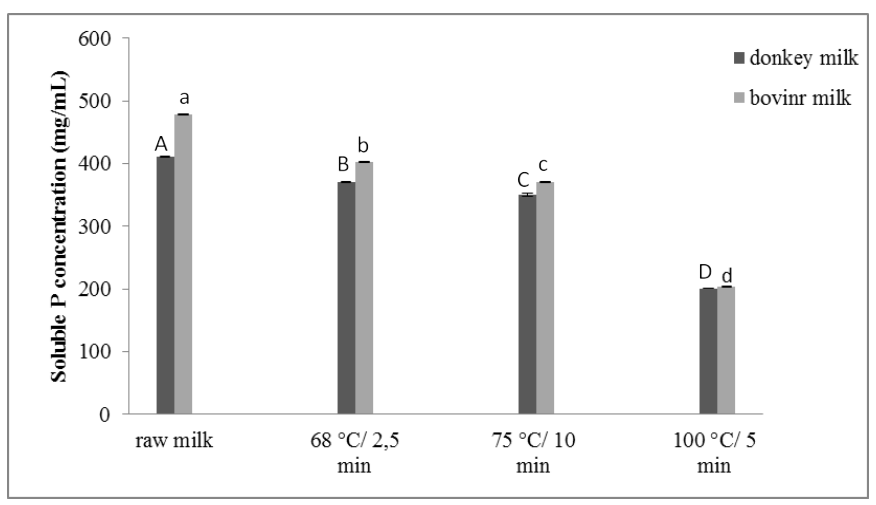

Figure 1. Soluble calcium (A) and phosphorous (B) concentration in raw and the differently heated samples. Different letters indicate a significant effect $(P<0.05)$ established by the heat treatment

\section{Microbiological analysis}

To evaluate the effect of heat treatment on the microbiological quality of donkey milk and that of bovine milk, some bacterial groups of raw milk and treated milks were enumerated. The results of Total Bacterial Count $(\mathrm{TBC})$ in tested donkey milk were lower $\left(2.57 \times 10^{4}\right.$ $\left.\mathrm{CFU} \mathrm{mL}{ }^{-1}\right)$ than that found in tested bovine milk $\left(2.33 \times 10^{6} \mathrm{CFU} \mathrm{mL} \mathrm{mL}^{-1}\right)$. Generally, raw donkey milk has lower TBC in comparison to that in milk from other sources [38,39], probably due to its high concentration of lysozyme [2]. Regarding heat treatment effects, it was found that the TBC of raw donkey and bovine milks was reduced approximately one order of magnitude in milk samples treated at $68^{\circ} \mathrm{C} 2.5 \mathrm{~min}^{-1}\left(3.21 \times 10^{3}\right.$ and $2.16 \times 10^{5} \mathrm{CFU} \mathrm{mL}{ }^{-1}$, respectively) and about 2 orders of magnitude in milk samples treated at $75^{\circ} \mathrm{C} 10 \mathrm{~min}^{-1}\left(2.65 \times 10^{2}\right.$ and $2.36 \times 10^{4} \mathrm{CFU}$ $\mathrm{mL}^{-1}$, respectively). Initial Enterobacteriaceae and total coliforms enumerated in raw donkey and bovine milks were reduced to less than $10 \mathrm{CFU} \mathrm{mL}{ }^{-1}$ after treatment at $68^{\circ} \mathrm{C} 2.5 \mathrm{~min}^{-1}$. Fecal coliforms were not detected in all treated milk samples. No bacteria $\left(<10 \mathrm{CFU} \mathrm{mL}^{-1}\right)$ were 
detected in samples heated at $100^{\circ} \mathrm{C} 5 \mathrm{~min}^{-1}$, confirming the effectiveness of this sterilizing treatment.

\section{Conclusions}

The application of non-standard heat treatments demonstrated that physical and chemical changes were always determined and that the majority of components in donkey milk were more sensitive than that in bovine milk. From this study, a heat treatment similar, or slightly higher than $68^{\circ} \mathrm{C} 2.5 \mathrm{~min}^{-1}$, proved to sufficiently guarantee safety requirements and limited thermal damages in donkey milk. The peculiar lysozyme activity detected in donkey milk was especially preserved at heat treatment of $68^{\circ} \mathrm{C} 2.5 \mathrm{~min}^{-1}$, although this enzyme showed to be quite thermostable in intensively heated samples. Besides the evaluations made in the present work, the identification of further markers could be useful to make optimized heat treatment scales to donkey milk which showed different characteristics compared to ruminant milk.

\section{References}

1. Tesse R, Paglialunga C, Braccio S, Armenio L (2009) Adequacy and tolerance to ass's milk in an Italian cohort of children with cow's milk allergy. Ital J Pediatr 35: 19. [Crossref]

2. Vincenzetti S, Polidori P, Mariani P, Cam-mertoni N, Fantuz F, et al. (2008) Donkey's milk protein fractions characterization. Food Chem 106: 640-649.

3. Charfi I, Rezouga F, Mahlouf A, Bornaz S (2017) The behaviour of Arabian donkey milk during its acidification compared to bovine milk. Int J Dairy Techn 70: 1-7.

4. Sakkas L, Moutafi A, Moschopoulou E, Moatsou G (2014) Assessment of heat treatment of various types of milk. Food Chem 159: 293-301. [Crossref]

5. Setya Budi MA, Bhakti Etza S (2015) The reduction of aerobic bacterial counts of bovine milk as influenced by heat-treatments at pasteurisation temperatures. Food Sci 3: $465-472$.

6. Zamberlin Š, Samarzija D (2017) The effect of non-standard heat treatment of sheep's milk on physicochemical properties, sensory characteristics, and the bacterial viability of classical and probiotic yogurt. Food Chem 22: 562-568.

7. Cosentino C, Labella C, Elshafie HS, Camele I, Musto M, et al. (2016) Effects of different heat treatments on lysozyme quantity and antimicrobial activity of jenny milk. J Dairy Sci 99: 5173-5179.

8. Giacometti F, Bardasi L, Merialdi G, Morbarigazzi M, Federici S, et al. (2016) Shelf life of donkey milk subjected to different treatment and storage conditions. J Dairy Sci 99: 4291-4299.

9. Whernery U, Hanke B, Braun F, Johnson B (2003) The effect of heat treatment on some camel milk constituents. Preliminary report. Milchwissenschft 58: 5-6.

10. Tidona F, Charfi I, Povolo M, Pelizzola V, Carminati D, et al. (2015) Fermented beverage emulsion based on donkey milk with sunflower oil. Int J Food Sci Technol 50: 2644-2652.

11. AFNOR (1993) Milk and milk products. In: Methods of analysis. Paris, France: AFNOR.

12. Miller GL (1959) Use of dinitrosalicylic acid reagent for determination of reducing sugar. Anal Chem 31: 426-428.

13. Deeth HC, Fitz-Gerald CH, Wood AF (1975) A convenient method to determine the extent of lipolysis in milk. Aust J Dairy Technol 30: 109-111.

14. de la Fuente MA, Olano A, Juárez M (2002) Mineral balance in milk heated using microwave energy. J Agric Food Chem 50: 2274-2277. [Crossref]

15. Pien J (1968) Dosage du calcium dans le lait. Lait 48: 433-444.

16. Pien J (1969) Dosage du phosphore dans le lait. Lait 49: 175-188.

17. Morales FJ, Romero C, Jiménez-Pérez S (2000) Characterization of industrial processed milk by analysis of heat-induced changes. Int J Food Sci Technol 35: 193-200.

18. Ozturkoglu-Budak S (2016) Effect of different treatments on the stability of lysozyme, lactoferrin and -lactoglobulin in donkey's milk. Int J Dairy Technol 71: 36-45.

19. Salimei E, Fantuz F, Coppola R, Chiofalo B, Polidori P, et al. (2004) Composition and characteristics of ass's milk. Animal Res 53: 67-78.
20. Addo CNA, Ferragut V (2015) Evaluating the ultra-high-pressure homogenization (UHPH) and pasteurization effects on the quality and shelf life of donkey mill. Int $J$ Food S 4: 104-115.

21. Singh H (2004) Heat stability of milk. Int J Dairy Technol 57: 111-118.

22. Morales FJ, Romero C, Jiménez-Pérez S (1992) An enhanced liquid chromatographic method for 5- hydroxymethylfurfural determination in UHT milk. Chromatographia 33: 45-48.

23. Morales FJ, Jiménez-Pérez S (1999) HMF formation during heat-treatment of milktype products as related to milk fat content. J Food Sci 64: 855-859.

24. Berg HE (1993) Reactions of lactose during heat treatment of milk: a quantitative study Disseration, Agricultural University, Wageningen.

25. Ling ER (1946) The composition of milk. In: A textbook of dairy chemistry, London, UK: Great Britain by jabeold and sons, LTD, pp: 1-68.

26. Hamosh M, Peterson JA, Henderson TR, Scallan CD, Kiwan R, et al. (1999) Protective functions of human milk: The milk fat globule. Semin Perinatol 23: 242-249.

27. Cilliers FP, Gouws PA, Koutchma T, Engelbrecht, Y, Adriaanse C, et al. (2014) A microbiological, biochemical and sensory characterisation of bovine milk treated by heat and ultraviolet (UV) light for manufacturing Cheddar cheese. Innov Food Sci Emerg 23: 94-106.

28. Gathercole J, Reis MG, Agnew M, Reis MM, Humphrey R, et al. (2017) Molecular modification associated with the heat treatment of bovine milk. Int Dairy J 73: 74-83.

29. Pesic MB, Barac MB, Stanojevic SP, Ristic NM, Macej OD, et al. (2012) Heat induced casein-whey protein interactions at natural $\mathrm{pH}$ of milk: A comparison between caprine and bovine milk. Small Ruminant Res 108: 77-86.

30. Felfoul I, Jardin J, Gaucheron F, Attia H, Ayadi MA (2017) Proteomic profiling of came and cow milk proteins under heat treatment. Food Chem 216: 161-169. [Crossref]

31. O'Connell JE, Fox PF (2011) Heat stability of milk. In: Fuquay JW, Fox PF, McSweeney PLH (Eds.) (2nd ed.). Encyclopedia of dairy sciences, San Diego, CA, USA: Academic press, pp: 744-749.

32. Deckers D, Vanlint D, Callewaert L, Aertsen A, Michiels WC (2008) Role of the lysozyme inhibitor Ivy in growth or survival of Escherichia coli and Pseudomonas aeruginosa bacteria in hen egg white and in human saliva and breast milk. Appl Env Microbiol 14: 4434-4439.

33. Ibrahim HR, Higashiguchi S, Sugimoto Y, Aoki T (1997) Role of divalent cations in the novel bactericidal activity of the partially unfolded lysozyme. J Agric Food Chem 45: 89-94.

34. Polidori P, Vincenzetti S (2010) Differences of protein fractions among fresh, frozen and powdered donkey milk. Recent Pat Food Nutr Agric 2: 56-60.

35. Coppola R, Salimei E, Succi M, Sorrentino E, Nanni M, et al. (2002) Behaviour of Lactobacillus rhamnosus strains in ass's milk. Annals Microbiol 52: 55-60.

36. Vincenzetti S, Polidori P, Vita A (2007) Nutritional characteristitcs of donkey's milk protein fraction. In: Ling JR (ed.) Protein research trends. Nova Science Publishers Inc, New York, USA, pp: 207-225.

37. Cosentino C, Paolino R, Freschi P, Calluso AM (2013) Short communication: Jenny milk as an inhibitor of late blowing in cheese: A preliminary report. J Dairy Sci 96 $3547-3550$.

38. Morgan F, Massouras T, Barbosa M, Roseiro L, Ravasco F, et al. (2003) Characteristic of goat milk collected from small and medium enterprises in Greece, Portugal and France. Small Ruminant Res 47: 39-49.

39. Chye FY, Abdullah A, Ayob MK (2004) Bacteriological quality and safety of raw milk in Malaysia. Food Microbiol 21: 535-541.

Copyright: (C2019 Charfi I. This is an open-access article distributed under the terms of the Creative Commons Attribution License, which permits unrestricted use, distribution, and reproduction in any medium, provided the original author and source are credited. 